\section{Rat-bite fever in the animal laboratory: A precautionary note}

\author{
FRANK ETSCORN \\ New Mexico Institute of Mining and Technology \\ Socorro, New Mexico \\ and

\section{DANIEL D. BLODGETT \\ Bhasker Medical Clinic \\ Socorro, New Mexico}

People who work with rodents in laboratories eventually get bitten. In the majority of such cases, good hygiene and precautionary measures prevent serious consequences. A thorough cleansing of the wound with, for example, hydrogen peroxide or Betadine solution should always be performed immediately after any bite. The bite should be documented and reported to the laboratory supervisor and a physician should be consulted. Precautionary treatments include observing the wound for any swelling or redness and notifying the attending physician of any such occurrences.

Typically, rodent bites result only in soreness, but other problems can result. Rat-bite fever (RBF) is one of the more serious such problems. RBF is characterized by fever, palmar rash, and arthritis (Brown \& Nunemaker, 1942; Raffin \& Freemark, 1979). Complications include bacterial endocarditis or chronic joint disease, with untreated cases having an appreciable mortality rate (McCormack, Kaye, \& Hook, 1967; Raffin \& Freemark, 1979). Migratory polyarthritis is present in approximately $50 \%$ of the cases, and it is a hallmark of the disease (McCormack et al., 1967). Chills and gastrointestinal and respiratory-tract symptoms (bronchopneumonia) may occur with RBF (Lambe, McPhedran, Mertz, \& Stewart, 1973).

From $10 \%$ to $100 \%$ of otherwise healthy rats harbor the causative agent of RBF (Streptobacillus moniliformis) as normal nasopharyngeal flora, and around $10 \%$ of the estimated 14,000 annual bites in U.S. laboratories and in urban areas with poor sanitation result in RBF (Anderson, Leary, \& Manning, 1983). RBF has also occurred as a result of bites or scratches from mice, squirrels, weasels, cats, and dogs. The incidence of occurrence is low; however, when the disease does occur, it can go undetected, as physicians may be unfamiliar with its symptoms. The incubation period of RBF is usually anywhere from 1 to 10 days, but can be as long as 3 weeks (Anderson et al., 1983). RBF may also be caused by Spirillum

Address correspondence to Frank Etscorn, Department of Psychology, New Mexico Institute of Mining and Technology, Socorro, NM 87801 . minus, but this form is more common in Asia (McHugh, Bartlett, \& Raymond, 1985).

The treatment of choice appears to be penicillin $G$ (McCormack et al., 1967; Roughgarden, 1965). Roughgarden recommends at least 400,000 to 600,000 units per day for not less than 7 days. If clinical response does not occur within 2 days, he suggests increasing the dose to 1.2 million units per day. Although Streptobacillus moniliformis is sensitive to in vitro tetracycline, experience with this drug in RBF is extremely limited. Other potentially useful drugs include erythromycin, streptomycin, chloramphenicol, cephalothin, and clindamycin (Centers for Disease Control, 1984; Gunning, 1976; Parker, 1983).

Interestingly, a review of psychology laboratory manuals (Hart, 1976; Ost, Allison, Vance, \& Restle, 1969; Skinner, 1971; Webster, 1975; Wellman, 1986; Wilsoncroft \& Law, 1967) reveals that measures for dealing with rat bites either are nonexistent or are viewed "as a sort of initiation into a unique brotherhood" (Ost et al., 1969 , p. 4). In no case is the possibility of developing RBF even mentioned. This lack of instruction concerning treatment of bites and the symptoms of RBF may be commonplace in institutions that use lab animals.

Prevention of RBF obviously lies in the use of better animal handling techniques. In most cases, heavy leather gloves designed for animal handlers or gloves made of what is essentially chain mail are effective for handlers of small rodents. Workers in our lab have had success over the years by using a thick hand towel placed over the animal (which the handler restrains by holding its tail) when it is grasped for the required handling or injection. This towel technique is easily mastered by novice animal handlers, and the animals appear to resist this technique less than other handling methods.

Unfortunately, too much emphasis on the dangers of RBF may produce an even greater hesitation to handle rodents among students who already exhibit a reluctance to do so. In such cases, education and, most importantly, demonstrations of proper animal handling techniques should dispel such fears.

\section{REFERENCES}

Anderson, L. C., Leary, S. L., \& Manning, P. J. (1983). Rat-bite fever in animal research laboratory personnel. Laboratory Animal Science, 33, 292-294.

Brown, J. M., \& Nunemaker, J. C. (1942). Rat-bite fever: Review of American cases with re-evaluation of its etiology and report of cases. Bulletin of The Johns Hopkins Hospital, 70, 201.

Centers for Disease Control. (1984). Rat-bite fever in a college student-California. Morbidity \& Mortality Weekly Report, 33, 318-320.

GunNING, J. J. (1976). Rat-bite fevers. In G. W. Hunter, J. C. Swartzwelder, \& D. F. Clyde (Eds.), Tropical medicine (pp. 245-247). Philadelphia: W. B. Saunders. 
HaRT, B. L. (Ed.). (1976). Experimental psychobiology: A laboratory manual. San Francisco: W. H. Freeman.

Lambe, D. W., McPhedran, A. M., Mertz, J. A., \& Stewart, P. (1973). Streptobacillus moniliformis isolated from a case of Haverhill fever: Biochemical characterization and inhibitory effect of sodium polyanethol sulfonate. American Journal of Clinical Pathology, 60, 854-860.

McCormack, R. C., KAYE, C. D., \& HoOK, E. W. (1967). Endocarditis due to Streptobacillus moniliformis: A report of two cases and review of the literature. Journal of the American Medical Association, 200, 77.

MCHugh, T. P., Bartlett, R. L., \& Raymond, J. I. (1985). Rat bite fever: Report of a fatal case. Annals of Emergency Medicine, 14, 119-121.

Ost, J. W. P., Allison, J., Vance, W. B., \& Restle, F. A. (1969). A laboratory introduction to psychology. New York: Academic Press.

PARKer, R. H. (1983). Rate-bite fever. In P. D. Hoeprich (Ed.), Infectious diseases (pp. 1241-1243). Philadelphia: Harper \& Row.
Raffin, B. J., \& Freemark, M. (1979). Streptobacillary rat-bite fever: A pediatric problem. Pediatrics, 64, 214-217.

Roughgarden, J. W. (1965). Antimicrobial therapy of rat-bite fever. Archives of Internal Medicine, 116, 39.

Skinner, J. E. (1971). Neuroscience: A laboratory manual. Philadelphia: W. B. Saunders.

WEBSTER, W. G. (1975). Principles of research methodology in physiological psychology. New York: Harper \& Row.

WeLLMAN, P. J. (1986). Laboratory exercises in physiological psychology. Boston: Allyn \& Bacon.

WILSONCROFT, W. E., \& LAW, O. T. (1967). Laboratory manual for physiological psychology. Austin, TX: The Psychonomic Society.

(Manuscript received July 8, 1987;

revision accepted for publication September 5, 1987.) 